\title{
Influence of Cutting Date and Nitrogen Fertilizer Levels on Growth, Forage Yield, and Quality of Sudan Grass in a Semiarid Environment
}

\author{
S. J. L. Ziki ${ }^{1},{ }^{1}$ E. M. I. Zeidan, ${ }^{2}$ A. Y. A. El-Banna, ${ }^{2}$ and A. E. A. Omar ${ }^{2}$ \\ ${ }^{1}$ Anim. Prod. Dept. Fac. Vet. Sci., Bahr El Ghazal University, Wau, Sudan \\ ${ }^{2}$ Agronomy Department, Faculty of Agriculture, Zagazig University, Zagazig, Egypt
}

Correspondence should be addressed to S. J. L. Ziki; samuelziki@yahoo.com

Received 14 June 2019; Accepted 22 August 2019; Published 15 September 2019

Academic Editor: Rodomiro Ortiz

Copyright (c) 2019 S. J. L. Ziki et al. This is an open access article distributed under the Creative Commons Attribution License, which permits unrestricted use, distribution, and reproduction in any medium, provided the original work is properly cited.

\begin{abstract}
Sudan grass is less sensitive to water shortage and produces large amounts of biomass. For these reasons, it is a promising summer forage crop for arid and semiarid regions where natural pastures are rare and water scarcity limits summer forage production. The aim of the present work was to investigate the influence of cutting date (early and late, for three cuts) and three nitrogen (N) fertilizer levels $(35,70$, and $105 \mathrm{~kg} \mathrm{~N} / \mathrm{ha} /$ cut) on Sudan grass (Sorghum sudanense (Piper) Stapf.). The study was carried out in the experimental farm of Faculty of Agriculture, Zagazig University, Egypt, during 2016 and 2017 summer seasons using a split-plot design. The results obtained revealed significant differences between the two cutting dates on growth, forage yield, and quality of Sudan grass. The late cutting date (56 days after sowing DAS and 42 days after the $1^{\text {st }}$ cut) gave the highest values for almost all the growth characters, dry forage yield in addition to total dry yield (TDY) in both seasons. The highest number of shoots/plant (1.911), leaf area/plant $\left(2841.6 \mathrm{~cm}^{2}\right)$, and dry forage weight $(\mathrm{g}) /$ plant $(76.65 \mathrm{~g})$ were obtained by late cutting (56 DAS) with the application of $105 \mathrm{~kg} \mathrm{~N} / \mathrm{ha} /$ cut. The lowest values of these characters were recorded with $35 \mathrm{~kg} \mathrm{~N} / \mathrm{ha} /$ cut. Quality parameters were significantly affected by $\mathrm{N}$ levels during both seasons, while cutting date significantly affected the protein yield ( $\mathrm{kg} / \mathrm{ha})$. The interaction result apparently indicated that the highest dry forage yield of Sudan grass $\left(16.26\right.$ ton/ha) was achievable at the $1^{\text {st }}$ cut with the application of the highest $\mathrm{N}$ level $(105 \mathrm{~kg} \mathrm{~N} / \mathrm{ha} /$ cut $)$.
\end{abstract}

\section{Introduction}

Sudan grass is a promising summer forage crop essentially in arid and semiarid regions as it is less sensitive to water shortage and produces large amounts of biomass [1]. In Egypt, livestock rearing suffers from feed deficiency because of the growing competition between the production of human food and animal feed. The problem reaches the peak during summer seasons, at this time Egypt faces lack of forage supply that can support its 18.4 million head of livestock, mostly cattle and buffaloes, i.e., dairy and beef [2]. Current efforts directed by local forage producers are chiefly focused on increasing the productivity and quality of some of the favorable annual forage crops such as Sudan grass, fodder maize, or millets [3, 4]. Sudan grass (Sorghum sudanense (Piper) Stapf.) stands as an important short-term annual and summer season forage crop widely grown in Egypt to balance the desperate demands by the livestock industry. It is recognized among the most satisfactory summer forage resources cultivated under irrigation system in many of the arid and semiarid parts of the country [5]. Area cultivated with Sudan grass reached about 3500 ha producing 190913 tons, with average production around 9.2 tons/ha [6].

Sudan grass as a forage crop has many reliable characters that include high yielding potential, drought and heat tolerance, very good water use efficiency, high response to $\mathrm{N}$ fertilization, less susceptibility to disease, and most importantly the crop's ability to provide 2-3 cuts per growing season [7]. The green foliage of Sudan grass is succulent, very palatable, and nutritious feed for dairy cattle. It represents an ideal bulky feed crop due to its dense vegetative growth and 
high dry yield. In this context, improving the growth, forage yield, and quality of Sudan grass requires the adoption of suitable agronomic practices among which cutting time and nitrogen fertilization are important $[8,9]$. Field observations and research findings have established that earlier cutting of sorghum plants would provide higher quality, while late cutting could produce higher forage yield $[5,10,11]$. Moreover, most farmers usually decide to harvest their forage crops more or less dependent on market demand without consideration to proper cutting time that can produce highest forage attributes [12]. Therefore, choosing the best cutting date should be managed, particularly that Sudan grass is a multicut crop. Furthermore, nitrogen as an essential nutrient needed by plants is much required for improved agronomy of Sudan grass under the agroclimatic and deprived soil conditions in dry areas [13]. Egypt agricultural soils are known for acute deficit in nitrogen content [14]. Thus, provision of the most adequate levels of $\mathrm{N}$ can be of great importance to profuse the growth and maximize the yield and quality components in Sudan grass.

The present investigation was therefore carried out to evaluate the performance of Sudan grass to cutting dates and nitrogen fertilizer levels under the semiarid agroclimatic conditions of El-Sharkia Governorate in Egypt.

\section{Materials and Methods}

Two field experiments were conducted during two consecutive summer seasons 2016 and 2017 on clay soil at the experimental farm of the Faculty of Agriculture, Zagazig University at Sharkia Governorate, Egypt $\left(30^{\circ} 6^{\prime} \mathrm{N}\right.$ and $31^{\circ} 6^{\prime} \mathrm{E}$ ). Soil samples from $30 \mathrm{~cm}$ depth were taken to determine the physical and chemical properties of the soil (Table 1). In addition, meteorological data, i.e., averages of minimum and maximum air temperatures and relative humidity during the growing period (from April to September in the first and second seasons), are presented in Table 2. Treatments consisted of two cutting dates (early and late) and three nitrogen levels (35, 70, and $105 \mathrm{~kg} \mathrm{~N} /$ ha/cut) using a Sudan grass cultivar Giza-2. The early cutting date in the $1^{\text {st }}$ cut was taken at 49 DAS, and the late cutting was taken at 56 DAS. The early and late cutting dates in the $2^{\text {nd }}$ cut were taken after 35 and 42 days from the $1^{\text {st }}$ cut, and the same schedule was done for the $3^{\text {rd }}$ cut, respectively. The experiments were laid out in a split plot design with three replications, where cutting dates were assigned to the main plots and nitrogen fertilizer levels occupied the sub plots. The preceding crop was faba bean (Vicia faba L.) during both seasons. Grains of the Sudan grass Giza-2 were sown on April $28^{\text {th }}$ and May $20^{\text {th }}$ in the first and second seasons, respectively. Sowing was done in hills on rows, with $10 \mathrm{~cm}$ distance between hills and $60 \mathrm{~cm}$ between rows. The experimental plot area was $10.5 \mathrm{~m}^{2}$, i.e., $2.5 \mathrm{~m}$ width and $4.2 \mathrm{~m}$ length, with each plot containing 7 ridges. Thinning was done at 14 DAS leaving two plants per hill to obtain a population of 140,000 plants/ha. Nitrogen fertilizer was applied in the form of ammonium nitrate $(33.5 \% \mathrm{~N})$, while weed control was carried out
Table 1: Physical and chemical properties of soil at the experimental site.

\begin{tabular}{lc}
\hline Characteristics & Value \\
\hline Soil particle distribution & \\
Sand (\%) & 17.45 \\
Silt (\%) & 22.70 \\
Clay (\%) & 59.85 \\
Soil texture & Clay \\
pH $(1: 2.5$ soil-water suspension) & 7.23 \\
Soluble cations and anions (mmolc $\left.{ }^{-1}\right)^{*}$ & \\
Calcium $\left(\mathrm{Ca}^{++}\right)$ & 5.0 \\
Magnesium $\left(\mathrm{Mg}^{++}\right)$ & 5.5 \\
Carbonate $\left(\mathrm{CO}_{3}^{=}\right)$ & - \\
Bicarbonate $\left(\mathrm{HCO}_{3}^{-}\right)$ & 0.50 \\
Chlorine $\left(\mathrm{Cl}^{-}\right)$ & 6.00 \\
Sulphate $\left(\mathrm{SO}_{4}^{=}\right)$ & 11.10 \\
Available nutrient $\left(\mathrm{mg} \mathrm{kg}^{-1}\right.$ soil) & \\
Total N $(\%)$ & 0.08 \\
Available $\mathrm{P}(\mathrm{ppm})$ & 9.08 \\
Potassium $(\mathrm{K})$ & 0.10 \\
\hline
\end{tabular}

TABle 2: Air temperatures $\left({ }^{\circ} \mathrm{C}\right)$ and relative humidity (\%) during the two growing seasons at the experimental site.

\begin{tabular}{lcccccc}
\hline \multirow{3}{*}{ Month } & \multicolumn{3}{c}{ Temperature $\left({ }^{\circ} \mathrm{C}\right)$} & \multicolumn{3}{c}{ Humidity (\%) } \\
& Min. & Max. & Avg. & Min. & Max. & Avg. \\
\hline 2016 season & & & & & & \\
May & 20.8 & 32.9 & 26.9 & 9.3 & 21.4 & 15.4 \\
June & 24.2 & 36.7 & 30.5 & 8.9 & 22.7 & 15.8 \\
July & 24.8 & 35.1 & 30.1 & 4.1 & 27.8 & 15.9 \\
Aug & 25.1 & 35.0 & 30.1 & 3.8 & 28.2 & 16.0 \\
Sep & 23.6 & 33.4 & 28.4 & 3.9 & 26.8 & 15.4 \\
\hline 2017 season & & & & & & \\
May & 20.2 & 31.8 & 26.0 & 10.0 & 24.2 & 17.1 \\
June & 23.4 & 35.2 & 29.3 & 7.5 & 26.1 & 16.8 \\
July & 25.5 & 35.4 & 30.1 & 5.5 & 29.2 & 17.4 \\
Aug & 25.6 & 35.1 & 30.5 & 3.2 & 28.7 & 15.9 \\
Sep & 23.3 & 31.2 & 27.3 & 3.6 & 28.2 & 15.9 \\
\hline
\end{tabular}

manually using hoes. A surface irrigation system was used, and the other culture practices for the crop were applied according to the recommendations of Ministry of Agriculture.

\section{Recorded Data}

3.1. Growth Characters. In order to measure the studied growth characters, five guarded plants were randomly taken from the $2^{\text {nd }}$ and $6^{\text {th }}$ ridges of each plot, respectively.

3.1.1. The Vegetative Measurements. The vegetative measurements such as the number of shoots per plant, leaf area per plant $\left(\mathrm{cm}^{2}\right)$, and dry forage weight per plant $(\mathrm{g})$ were calculated using the following equation:maximum length$\times$ maximum width $\times 0.72 \times$ number of leaves per plant.

3.1.2. Forage Yield. Dry forage yield (ton/ha) was determined in the lab using a $500 \mathrm{~g}$ subsample collected from 
the fresh weights, oven dried at a constant temperature of $70^{\circ} \mathrm{C}$ for 48 hours accordingly.

3.1.3. Forage Quality. Forage quality was determined on the samples of the $1^{\text {st }}$ and $2^{\text {nd }}$ cuts only, in both seasons. The crude protein content $(\mathrm{CP} \%)$ in leaves and stems was determined using the modified Kjeldahl method and by multiplying the nitrogen percentage by 5.75 the protein content can be obtained accordingly [15]. Protein yield (kg/ ha) was estimated using the following formula: forage dry yield (ton $/$ ha) $\times \mathrm{CP} \%$.

3.2. Statistical Analysis. Data of the two seasons were statistically analyzed according to the methods outlined by Steel et al. [16], whereas the significance of differences among various means of different characters under the study was compared with the help of Duncan's multiple range tests [17].

\section{Results and Discussion}

Results of the two seasons were displayed separately due to the variation in the sowing date (April $28^{\text {th }}$ and May $20^{\text {th }}$ in the first and second seasons, respectively). Considering this variation, no combined result was therefore introduced.

\subsection{Growth Characters}

4.1.1. Number of Shoots per Plant. The number of shoots per plant is an important yield contributing character that may affect the forage yield of Sudan grass. Results obtained in Table 3 show that the number of shoots per plant significantly is affected by cutting date in all cuts in the first season and $2^{\text {nd }}$ cut in the second season. The highest number of shoots per plant $(1.911,1.637$, and 1.581) was recorded at the $1^{\text {st }}$ late cutting (56 DAS) and $2^{\text {nd }}$ and $1^{\text {st }}$ early cutting (35 days after $1^{\text {st }}$ cut and 49 DAS) in the first season. However, results clearly indicated that the early cutting date was in favor of obtaining higher number of shoots per plant compared to late cutting in both seasons. The present finding suggests that the earlier cutting date of Sudan grass coincides with higher tillering, which may stimulate more number of shoots per plant, respectively. These results are comparable to those obtained by Sowiński and Szydełko [18], Thuranira et al. [9], and Ibrahim et al. [5]. Consequently, $\mathrm{N}$ fertilizer levels recorded significant differences in both seasons. The mean-through was significantly increased as the $\mathrm{N}$ level was increased from 35 up to $105 \mathrm{~kg} \mathrm{~N} / \mathrm{ha} /$ cut. The relative increase in the number of shoots per plant due to the increased $\mathrm{N}$ level up to $105 \mathrm{~kg} \mathrm{~N} / \mathrm{ha} /$ cut was $76.65 \%, 88.55 \%$, and $88.60 \%$ in the $1^{\text {st }}, 2^{\text {nd }}$, and $3^{\text {rd }}$ cuts in the first season, as well as $61.37 \%$ and $56.95 \%$ at the $2^{\text {nd }}$ and $3^{\text {rd }}$ cuts during the second season, respectively. These results prove the positive response in Sudan grass to higher applied N level $105 \mathrm{~kg} \mathrm{~N} /$ ha/cut which resulted in increased number of shoots per plant (Table 3). Furthermore, the interaction results between cutting date and $\mathrm{N}$ fertilizer levels on the number of shoots per plant were highly significant for all the cuts in the first season, while nonsignificant during the second season.
Based on the significant interaction, the highest number of shoots per plant (2.40) was obtainable by late cutting at the $1^{\text {st }}$ cut in the first season under application of the highest $\mathrm{N}$ level (105 kg N/ha/cut) (Figure 1). Mahmoud et al. [19] reported similar findings, which emphasized the role of externally supplied $\mathrm{N}$ in enhancing the vegetative growth in sorghum forage crop. In addition, Ibrahim et al. [5] reported relevant response in all the growth attributes and yield of this sorghum Sudan grass cultivar Giza-2 (Sorghum sudanense (Piper) Stapf.) under the $\mathrm{N}$ level of $45 \mathrm{~kg} \mathrm{~N} / \mathrm{fad} /$ cut.

4.1.2. Leaf Area (LA) $\left(\mathrm{cm}^{2}\right)$ per Plant. The leaf area (LA) parameter is an important vegetation variable that affects light capture by crop, thus stimulating photosynthesis and carbohydrate production [20]. The results obtained revealed highly significant differences for early and late cutting dates in both seasons (Table 3). Obviously, over the three cuts, early cutting taken ( 35 days after $1^{\text {st }}$ and $2^{\text {nd }}$ cuts, respectively) recorded higher LA per plant values $\left(1140.3,2648.9\right.$, and $\left.1060.6 \mathrm{~cm}^{2}\right)$ at the $3^{\text {rd }}$ cut in the first season and the $2^{\text {nd }}$ and $3^{\text {rd }}$ cuts in the second season, whereas late cutting produced the highest LA values per plant $\left(2841.6,1648.2\right.$, and $\left.2573.8 \mathrm{~cm}^{2}\right)$ in the $1^{\text {st }}$ and $2^{\text {nd }}$ cuts (56 DAS and 42 days after the $1^{\text {st }}$ cut) in the first season, as well as in the $1^{\text {st }}$ late cutting (56 DAS) of the second season, respectively. Cutting on 56 DAS gave the maximum LA $\left(2841.6 \mathrm{~cm}^{2} /\right.$ plant $)$ at $1^{\text {st }}$ cut in the first season, while the minimum LA $\left(947.10 \mathrm{~cm}^{2} /\right.$ plant $)$ was recorded at the $3^{\text {rd }}$ late cutting ( 42 days after $2^{\text {nd }}$ cut) in the second season (Table 3 ). Earlier, Mughan et al. [21] noticed that the leaf development in sorghum plants was linearly associated with the growing point by day. However, the present results indicated that Sudan grass LA seems to reach the largest possible with crop growth until the first cut and then drops back at the second and third cuts. The highest LA obtained during late cutting dates could be due to extra growing time (seven more days after early cutting), which might have allowed for more vegetative growth and development. These results are in consistent with those ascribed by Yagoub and Abdelsalam [22], Atis et al. [10], and Ibrahim et al. [5]. Regarding the influence of $\mathrm{N}$ fertilizer levels, data obtained (Table 3 ) showed highly significant differences among applied $\mathrm{N}$ levels in both seasons. Apparently, application of the highest level (105 kg N/ha/cut) significantly produced the largest LA $\left(\mathrm{cm}^{2}\right)$ per plant, such as $3303.9 \mathrm{~cm}^{2}, 1880.8 \mathrm{~cm}^{2}$, and $1222.7 \mathrm{~cm}^{2}$ at the $1^{\text {st }}, 2^{\text {nd }}$, and $3^{\text {rd }}$ cuts in the first season, respectively. While expectedly, the smallest LA values were attained by the application of the lowest level ( $35 \mathrm{~kg} \mathrm{~N} / \mathrm{ha} / \mathrm{cut})$. The same trend was detected in the second season. Relative increase in LA $\left(\mathrm{cm}^{2}\right)$ per plant due to the increased $\mathrm{N}$ level from 35 to $105 \mathrm{~kg} \mathrm{~N} / \mathrm{ha} /$ cut was $43.7 \%, 72.05 \%$, and $45.98 \%$ at the $1^{\text {st }}$, $2^{\text {nd }}$, and $3^{\text {rd }}$ cuts, respectively. On the other hand, the obtained results revealed a highly significant effect for the interaction between cutting date and $\mathrm{N}$ fertilizer levels on the LA per plant across all the cuts in both seasons, whereby the maximum LA per plant $\left(3348.2 \mathrm{~cm}^{2}\right)$ was achievable in the $1^{\text {st }}$ late cutting of the first season, with application of the highest $\mathrm{N}$ level $(105 \mathrm{~kg} \mathrm{~N} / \mathrm{ha} / \mathrm{cut}$ ) (Figure 2). The significant increase in LA with increased $\mathrm{N}$ fertilizer levels could be attributed to the significant role by $\mathrm{N}$ availability in triggering the photosynthetic and 
TABLE 3: Effect of the cutting date and nitrogen fertilizer on the number of shoots per plant, leaf area, dry forage weight per plant, and dry forage yield of Sudan grass (tons/ha) during 2016 and 2017 summer seasons.

\begin{tabular}{|c|c|c|c|c|c|c|c|c|c|c|c|c|c|}
\hline \multirow{2}{*}{$\begin{array}{l}\text { Treatments and } \\
\text { interactions }\end{array}$} & \multicolumn{3}{|c|}{ Number of shoots/plant } & \multicolumn{3}{|c|}{ Leaf area $\left(\mathrm{cm}^{2}\right) /$ plant } & \multicolumn{3}{|c|}{$\begin{array}{l}\text { Dry forage weight }(\mathrm{g}) / \\
\text { plant }\end{array}$} & \multicolumn{4}{|c|}{ Dry forage yield (ton/ha) } \\
\hline & $1^{\text {st }}$ cut & $2^{\text {nd }}$ cut & $3^{\text {rd }}$ cut & $1^{\text {st }}$ cut & $2^{\text {nd }}$ cut & $3^{\text {rd }}$ cut & $1^{\text {st }}$ cut & $2^{\text {nd }}$ cut & $3^{\text {rd }}$ cut & $1^{\text {st }}$ cut & $2^{\text {nd }}$ cut & $3^{\text {rd }}$ cut & TDY \\
\hline \multicolumn{14}{|l|}{ Season 2016} \\
\hline \multicolumn{14}{|l|}{ Cutting date (D) } \\
\hline Early & $1.581 b$ & $1.637 \mathrm{a}$ & $1.150 \mathrm{a}$ & $2523.6 b$ & $1516.3 \mathrm{~b}$ & $1140.3 \mathrm{a}$ & $41.11 b$ & $46.60 \mathrm{~b}$ & $37.95 a$ & 10.14 & 10.02 & $4.16 \mathrm{~b}$ & 24.31 \\
\hline Late & $1.911 \mathrm{a}$ & $1.556 \mathrm{~b}$ & $0.778 b$ & $2841.6 a$ & $1648.2 \mathrm{a}$ & $1110.3 \mathrm{~b}$ & $55.05 \mathrm{a}$ & $64.01 \mathrm{a}$ & $30.94 \mathrm{~b}$ & 12.51 & 10.03 & $5.07 \mathrm{a}$ & 27.62 \\
\hline$F$ test & $* *$ & $*$ & ** & $* *$ & $* *$ & $* *$ & $* *$ & $* *$ & $* *$ & NS & NS & $*$ & NS \\
\hline \multicolumn{14}{|c|}{$\begin{array}{l}\text { Nitrogen levels (kg N/ } \\
\text { ha/cut) }\end{array}$} \\
\hline $35 \mathrm{~kg}$ & $1.255 \mathrm{c}$ & $1.118 \mathrm{c}$ & $0.667 c$ & $1998.3 c$ & $1385.4 \mathrm{c}$ & $1043.3 c$ & $38.59 \mathrm{c}$ & $45.17 \mathrm{c}$ & $28.98 \mathrm{c}$ & $6.87 c$ & $9.40 \mathrm{~b}$ & $4.17 \mathrm{~b}$ & $20.45 c$ \\
\hline $70 \mathrm{~kg}$ & $1.767 \mathrm{~b}$ & $1.562 \mathrm{~b}$ & $0.967 \mathrm{~b}$ & $2745.7 \mathrm{~b}$ & $1480.6 \mathrm{~b}$ & $1109.9 b$ & $48.24 \mathrm{~b}$ & $50.50 \mathrm{~b}$ & $33.49 b$ & $11.04 \mathrm{~b}$ & $10.04 \mathrm{ab}$ & $4.11 \mathrm{~b}$ & $25.19 b$ \\
\hline $105 \mathrm{~kg}$ & $2.217 \mathrm{a}$ & $2.108 \mathrm{a}$ & $1.258 \mathrm{a}$ & $3303.9 \mathrm{a}$ & $1880.8 \mathrm{a}$ & $1222.7 \mathrm{a}$ & $56.76 \mathrm{a}$ & $69.30 \mathrm{a}$ & $42.37 \mathrm{a}$ & $16.06 \mathrm{a}$ & $10.64 a$ & $5.56 \mathrm{a}$ & $32.26 \mathrm{a}$ \\
\hline$F$ test & $* *$ & $* *$ & $* *$ & $* *$ & $* *$ & $* *$ & $* *$ & $* *$ & $* *$ & $* *$ & $*$ & $* *$ & $* *$ \\
\hline Interactions $\mathrm{D} \times \mathrm{N}$ & $* *$ & $* *$ & $* *$ & $* *$ & $* *$ & $* *$ & $* *$ & $* *$ & $* *$ & $* *$ & NS & $*$ & $* *$ \\
\hline \multicolumn{14}{|l|}{ Season 2017} \\
\hline \multicolumn{14}{|l|}{ Cutting date (D) } \\
\hline Early & 0.722 & $1.444 \mathrm{a}$ & 0.689 & $2180.5 b$ & $2648.9 a$ & $1060.6 \mathrm{a}$ & $52.45 b$ & $44.36 \mathrm{~b}$ & $23.48 \mathrm{a}$ & $6.20 \mathrm{~b}$ & $5.62 b$ & 2.74 & $14.56 \mathrm{~b}$ \\
\hline Late & 0.711 & $1.156 b$ & 0.533 & $2573.8 \mathrm{a}$ & $2349.8 b$ & $947.10 \mathrm{~b}$ & $76.65 a$ & $71.82 \mathrm{a}$ & $20.52 b$ & $10.00 \mathrm{a}$ & $9.09 a$ & 2.45 & $21.55 \mathrm{a}$ \\
\hline$F$ test & NS & $*$ & NS & $* *$ & $* *$ & $* *$ & $* *$ & $* *$ & $* *$ & $* *$ & $* *$ & NS & $* *$ \\
\hline \multicolumn{14}{|c|}{$\begin{array}{l}\text { Nitrogen levels (kg N/ } \\
\text { ha/cut) }\end{array}$} \\
\hline $35 \mathrm{~kg}$ & 0.633 & $1.033 \mathrm{~b}$ & $0.467 \mathrm{~b}$ & $1896.3 \mathrm{c}$ & $1851.0 \mathrm{c}$ & $870.8 b$ & $53.85 \mathrm{c}$ & $45.84 \mathrm{c}$ & $19.74 \mathrm{c}$ & $7.48 \mathrm{c}$ & $6.61 \mathrm{c}$ & $2.21 \mathrm{~b}$ & $16.30 \mathrm{~b}$ \\
\hline $70 \mathrm{~kg}$ & 0.650 & $1.200 \mathrm{~b}$ & $0.633 \mathrm{ab}$ & $2510.1 b$ & $2462.0 \mathrm{~b}$ & $869.6 b$ & $69.28 \mathrm{a}$ & $60.53 b$ & $21.54 \mathrm{~b}$ & $8.28 b$ & $7.92 \mathrm{a}$ & $2.42 \mathrm{~b}$ & $18.62 \mathrm{a}$ \\
\hline $105 \mathrm{~kg}$ & 0.867 & $1.667 \mathrm{a}$ & $0.733 \mathrm{a}$ & $2725.0 \mathrm{a}$ & $3184.8 \mathrm{a}$ & $1271.2 \mathrm{a}$ & $69.92 \mathrm{a}$ & $63.31 \mathrm{a}$ & $23.52 \mathrm{a}$ & $8.54 \mathrm{a}$ & $7.54 b$ & $3.17 \mathrm{a}$ & $19.26 \mathrm{a}$ \\
\hline$F$ test & NS & $* *$ & $*$ & $* *$ & $* *$ & $* *$ & $* *$ & $* *$ & $* *$ & $* *$ & $* *$ & $*$ & $* *$ \\
\hline Interactions $\mathrm{D} \times \mathrm{N}$ & NS & NS & NS & $* *$ & $* *$ & $* *$ & $* *$ & $* *$ & NS & NS & $* *$ & NS & NS \\
\hline
\end{tabular}

a, b, 'Significance level between the treatments, whereby 'a' is higher than 'b', 'b' higher than ' $c$ ', and 'ab' is of equal significance, in the respective order. ${ }^{*, * *}$ Significance at 0.05 and 0.01 levels; ${ }^{\mathrm{NS}}$ not significant

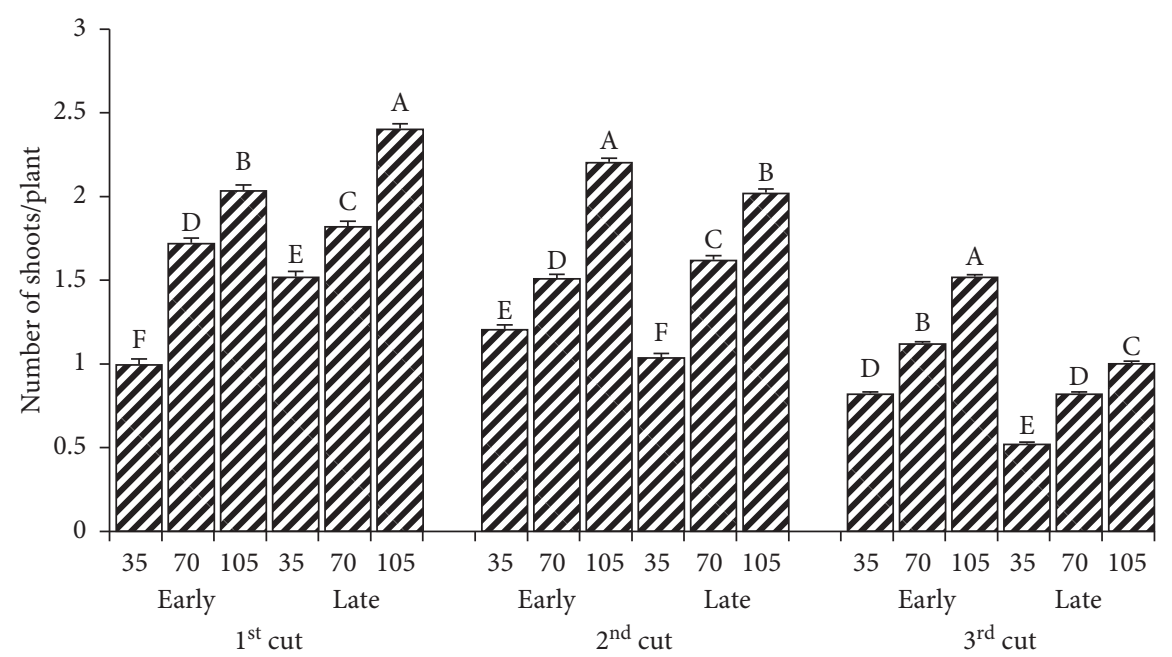

Figure 1: The number of shoots/plant of Sudan grass as affected by the interaction between cutting date and nitrogen fertilizer levels at the three cuts in the first season. The bars on the top of column represent the SE for each cut.

metabolic activities in the crop, which accelerated the vegetative growth and thus produced a wider LA per plant. Reports in $[5,19,23]$ indicated similar conclusions.

4.1.3. Dry Forage Weight (g) per Plant. Results illustrated in Table 3 show highly significant differences between early and late cutting dates on the dry forage weight $(\mathrm{g}) / \mathrm{plant}$ of Sudan grass in all cuts during both seasons. It is evident from the results that the dry forage weight significantly increased with late harvesting of the crop (56 DAS and 42 days after the $1^{\text {st }}$ cut, respectively) compared to that of the early cutting date, excluding the $3^{\text {rd }}$ cuts in both seasons, whereby early cutting ( 35 days after the $2^{\text {nd }}$ cut) gave higher values. In both seasons, the highest dry forage weight (76.65 (g)/plant) and the lowermost dry forage weight $(20.52(\mathrm{~g}) /$ plant $)$ were obtained 


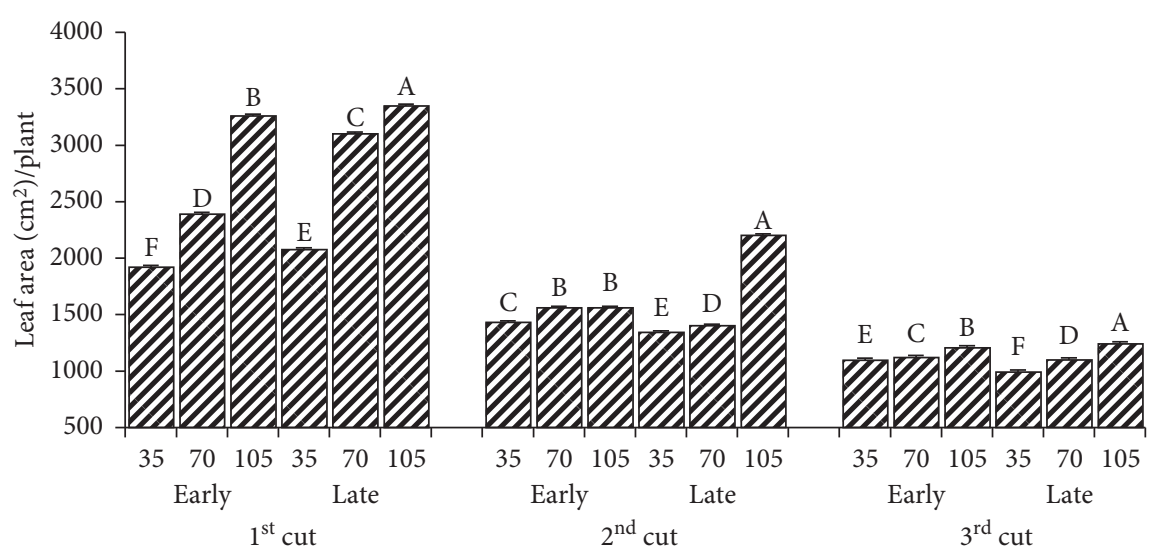

(a)

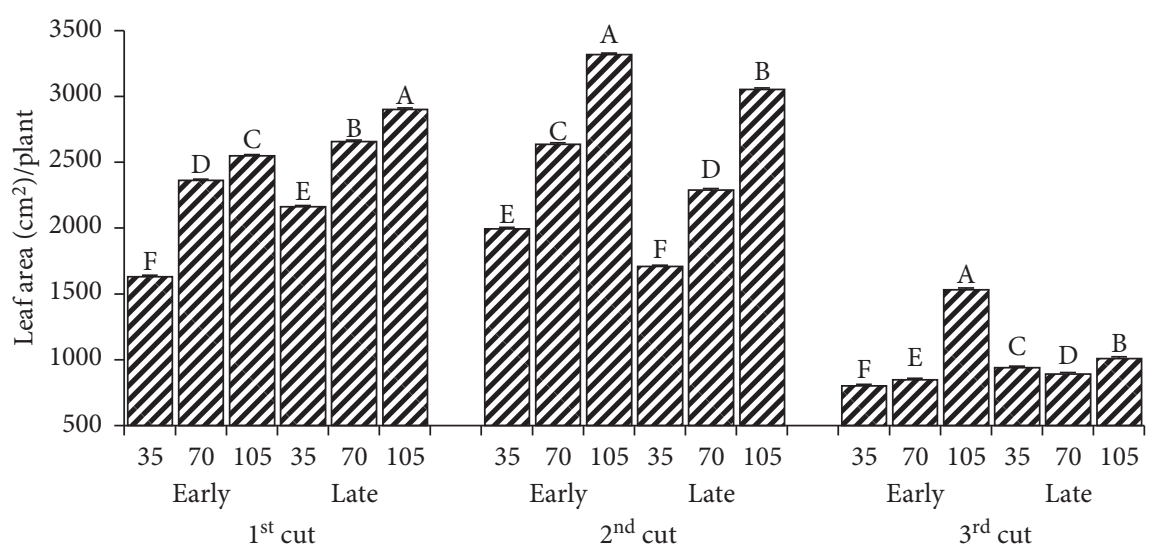

(b)

FIGURE 2: Leaf area $\mathrm{cm}^{2} /$ plant of Sudan grass as affected by the interaction between cutting date and nitrogen fertilizer levels at the three cuts in the first season (a) and the second season (b). The bars on the top of column represent the SE for each cut.

at the $1^{\text {st }}$ and $3^{\text {rd }}$ cuts at the late cutting date $(56$ DAS and 42 days after the $2^{\text {nd }}$ cut) in the second season accordingly. It could be explained from these results that, the more the Sudan grass plants advance in age with delayed cutting, the more the growth attributes such as the number of shoots and extra leaf area, therefore reflecting in more fresh weight and eventually high dry forage weight $(\mathrm{g}) /$ plant. This finding is quite useful if the target of crop production is higher forage yield. On the other hand, $\mathrm{N}$ fertilizer levels effect reflected highly significant differences in all the cuts in both seasons (Table 3). It was obvious that dry forage weight $(\mathrm{g}) /$ plant had increased with increased $\mathrm{N}$ levels. However, the highest values of the character were produced by application of the highest $\mathrm{N}$ level $(105 \mathrm{~kg} \mathrm{~N}$ ha/cut $)$ in both seasons, excluding the $1^{\text {st }}$ cut in the second season where no significant differences between using 35 and $70 \mathrm{~kg} \mathrm{~N} / \mathrm{ha} /$ cut were detected. These outcomes show that, $\mathrm{N}$ supply is essential for ensuring a significant increase in the dry forage weight per plant of Sudan grass crop. Consequently, the interaction data between cutting date and $\mathrm{N}$ fertilizer levels on the dry forage weight per plant showed a highly significant effect for all cuts during both seasons, excluding the $3^{\text {rd }}$ cut in the second season. From the interaction results, the highest attainable dry forage weight $(81.387 \mathrm{~g})$ was recorded at late cutting in the $1^{\text {st }}$ cut of the second season under the highest applied $\mathrm{N}$ level $(105 \mathrm{~kg} \mathrm{~N} / \mathrm{ha} /$ cut), respectively (Figure 3). Earlier, Yagoub and Abdelsalam [22] reported a significant increase in the dry forage weight of forage sorghum (Sorghum bicolor L Moench cv. Abusabien) with increased $\mathrm{N}$ application. More recently, Nirmal et al. [24] confirmed a significant increase in the forage weight (g)/plant of sorghum (Sorghum bicolor (Moench) L.) with a higher N level $(125 \mathrm{~kg} \mathrm{~N} / \mathrm{ha})$ compared to lower levels $(50,75$, and $100 \mathrm{~kg} / \mathrm{N} / \mathrm{ha})$, respectively. These results are in line with those reported by Moghimi and Emam [25], El Zubair et al. [26], and Somashekar et al. [27].

\subsection{Forage Yield}

4.2.1. Dry Forage Yield (tons/ha). The cutting date had significantly affected the dry forage yield (ton/ha) of Sudan grass at the $3^{\text {rd }}$ cut in the first season, and the $1^{\text {st }}$ and $2^{\text {nd }}$ cuts in the second season, respectively (Table 3 ). However, differences between early and late cuttings reached no significant level at both the $1^{\text {st }}$ and $2^{\text {nd }}$ cuts in the first season and the $3^{\text {rd }}$ cut of the second season accordingly. Generally, the maximum obtained dry yield (ton/ha) values were recorded on late cutting compared to early cutting in both seasons. In the first season, delayed cutting ( 42 days after the $2^{\text {nd }}$ cut) gave higher dry forage yield of 5.07 ton/ha 


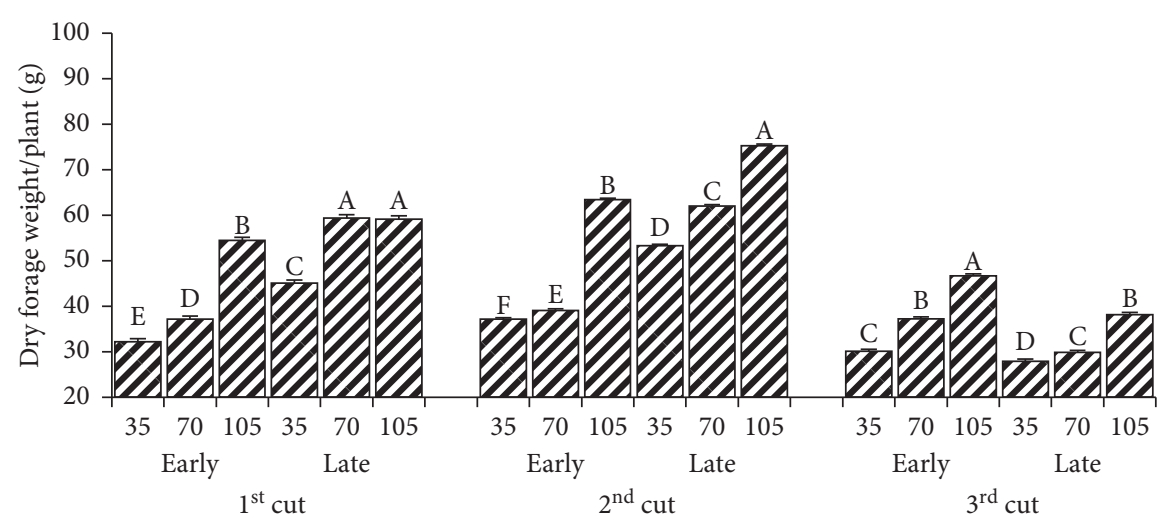

(a)

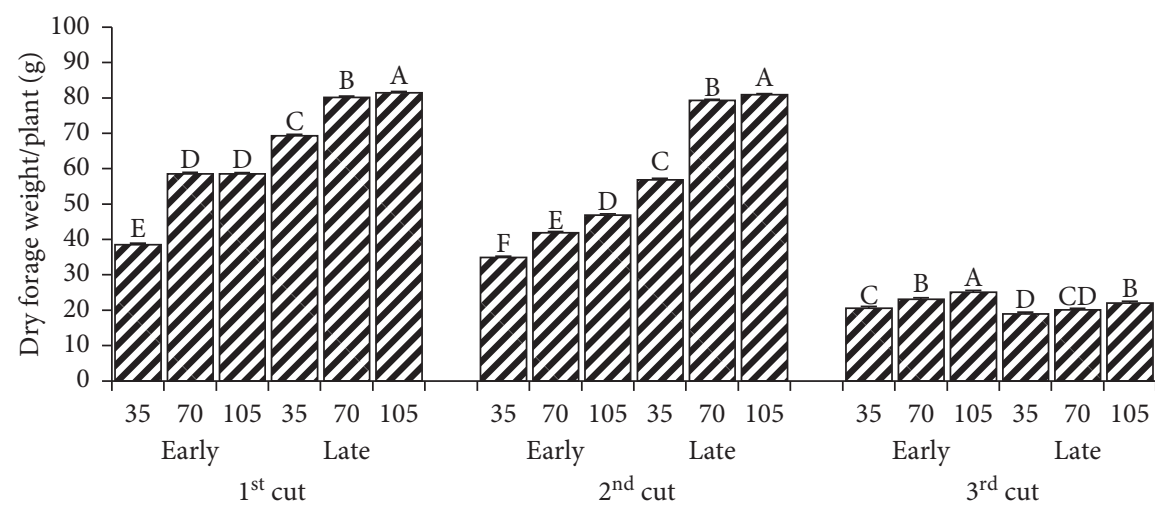

(b)

Figure 3: Dry forage weight/plant of Sudan grass as affected by the interaction between cutting date and nitrogen fertilizer levels at the three cuts in the first season (a) and the second season (b). The bars on the top of column represent the SE for each cut.

compared to early cutting (35 days after the $2^{\text {nd }}$ cut) which gave

4.16 ton/ha. Also, in the second season, late cuttings at the $1^{\text {st }}$ and $2^{\text {nd }}$ cuts (56 DAS and 42 days after the $1^{\text {st }}$ cut) produced significantly the highest dry forage yield values (10.00 and 9.09 ton/ha) in addition to TDY (21.55 ton/ha), respectively. The present results indicated that delaying the first cut of Sudan grass produced higher dry forage yield; however, a decrease in yield was noticed in the successive $2^{\text {nd }}$ and $3^{\text {rd }}$ cuts accordingly (Table 3). Ramamohan [28] had previously confirmed a decreased trend in the dry yield values in forage sorghum over three cuts. Dry yield is fundamental for vital carbohydrate components in forage crops to provide energy for livestock. Deciding the most proper cutting date for sorghum Sudan grass that target higher dry forage yield should be a priority to forage producers. These findings conform to reports by Machicek [7] who concluded that cutting forage sorghum (Sorghum bicolor (L.) Moench) at 90 DAS compared to 30 or 45 DAS produced significantly higher dry yield production. Furthermore, $\mathrm{N}$ fertilizer levels registered significant differences at all cuts in both seasons. Results obtained in Table 3 indicate that dry yield was significantly and steadily increased with the increasing $\mathrm{N}$ levels from 35 up to $105 \mathrm{~kg} \mathrm{~N} / \mathrm{ha} /$ cut, respectively. Application of the highest $\mathrm{N}$ level $(105 \mathrm{~kg} \mathrm{~N} / \mathrm{ha} / \mathrm{cut})$ produced significantly the highest dry yield (ton/ha) values during both seasons. Subsequently, the lowest values of these characters were recorded with application of the lowest level $35 \mathrm{~kg} \mathrm{~N} / \mathrm{ha} /$ cut. Yet, the increase in dry forage yield (ton/ha) with increased $\mathrm{N}$ levels could be attributed to the high response by Sudan grass crop to higher N levels, which resulted in enriched growth characters such as more number of shoots per plant, more leaf area per plant, more dry forage weight per plant, and eventually high dry forage yield of Sudan grass per unit area. Considering the poor soil conditions in Egypt and similar areas, attesting the most appropriate $\mathrm{N}$ quantity and role to maximize the yield in summer forage crops is agronomically and economically important. So far, the interaction result between the studied factors revealed a significant effect on dry forage yield at the $1^{\text {st }}$ cut in the first season (Figure 4) in which the highest dry yield value (16.26 ton/ha) was achievable by cutting Sudan grass under the late cutting date (56 DAS) with application of the highest $\mathrm{N}$ level (105 kg N/ha/cut). According to Afzal et al. [8], increasing the $\mathrm{N}$ dose from zero to 50,75 , and $100 \mathrm{~kg} \mathrm{~N} /$ acre increased the dry weight of sorghum forage. Also, Sharajabian and Soleymani [29] obtained the highest total dry matter of forage sorghum (Sorghum bicolor L.) by addition of the top N level ( $240 \mathrm{~kg} \mathrm{~N} / \mathrm{ha})$. Similarly, AboZeid et al. [30] reported a significant increase in Sudan grass dry forage yield as $\mathrm{N}$ rates were increased from 50 to 75 and then to $100 \mathrm{~kg} \mathrm{~N} / \mathrm{fad}$. 


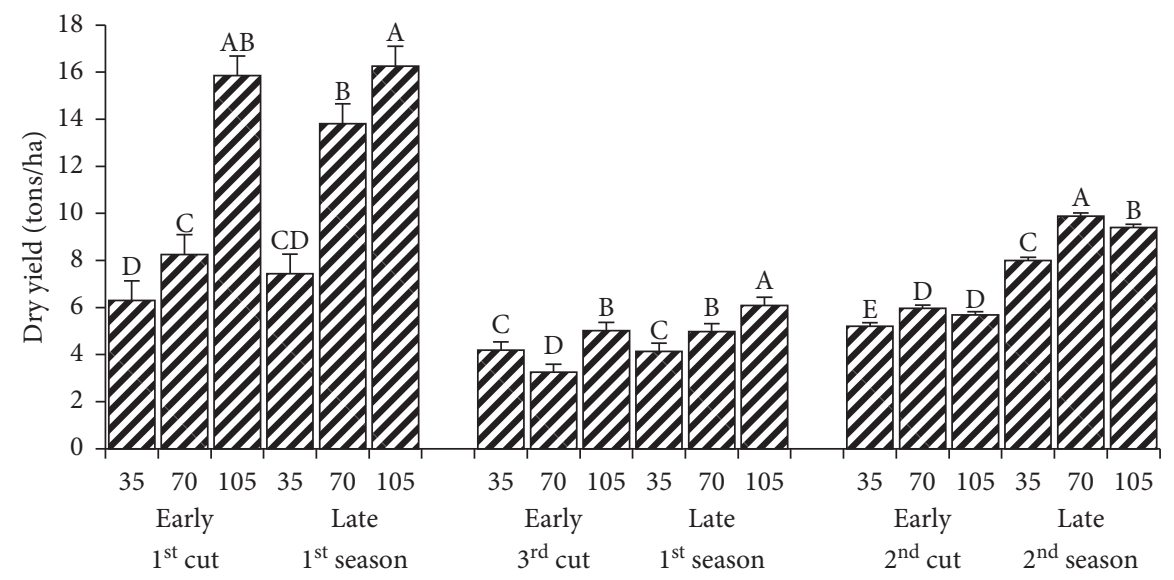

FiguRE 4: Dry forage yield of Sudan grass as affected by the interaction between cutting date and nitrogen fertilizer levels at the $1^{\text {st }}$ and $3^{\text {rd }}$ cuts in the first season and the $2^{\text {nd }}$ cut in the second season. The bars on the top of column represent the SE for each cut.

\subsection{Forage Quality}

4.3.1. Crude Protein Content (CP\%). Data presented in Table 4 show the effect of the cutting date and $\mathrm{N}$ fertilizer levels on the CP\% in Sudan grass. However, though differences between the applied cutting dates did not reach the level of significance, yet the obtained CP\% values are within the range of this quality parameter in Sudan grass as reported earlier in [5,31]. According to McCuistion [32], based on nutrient composition for ruminants (dairy and beef), the recommended CP\% falls between 10.53 and $12.60 \%$. The present insignificant results are contrary to those of Atis et al. [10] and Ibrahim et al. [5] who reported significant effects regarding the cutting time on the CP\%, which could be due to variances in agroclimatic conditions and soil fertility. Nevertheless, Afzal et al. [8] stated that delayed cutting of Sudan grass may increase the yield but the overall quality will be dropped. However, Machicek [7] pointed out that forage quality parameters of sorghum (Sorghum bicolor (L.) Moench) were sacrificed when cutting at 90 DAS compared to 45 DAS. Regarding the influence of $\mathrm{N}$ fertilizer levels, the results showed significant differences at both cuts in both seasons, whereby increasing the $\mathrm{N}$ fertilizer level from the lowest level up to the highest level caused significant increase in the CP\%(Table 4). Significantly, the highest CP\% was obtained by application of the uppermost $\mathrm{N}$ level (105 kg N/ha/cut). However, no statistical differences observed between the use of neither 70 nor $105 \mathrm{~kg} \mathrm{~N} / \mathrm{ha} / \mathrm{cut}$ at the $1^{\text {st }}$ cuts in both seasons on this parameter. Otherwise, increasing the $\mathrm{N}$ level was in favor of increased CP\% in Sudan grass under the study. Our findings hereby highlight that, agronomy practices that secure increasing the quality content in high yielding annual fodder species such as Sudan grass are beneficial to improve forage palatability and digestibility. This could be due to $\mathrm{N}$ being a structural component in amino acids makeup, which contributes to the buildup of proteins. Similar remarks on the increased crude protein content with increased $\mathrm{N}$ levels were reported by Midha et al. [33], El Shafey [34], Ibrahim et al. [5], and Naik [35].
TABLE 4: Crude protein content (\%) and protein yield $(\mathrm{kg} / \mathrm{ha})$ of Sudan grass as affected by cutting date and nitrogen fertilizer levels during 2016 and 2017 summer seasons.

\begin{tabular}{|c|c|c|c|c|}
\hline \multirow[t]{2}{*}{ Treatments and interactions } & \multicolumn{2}{|c|}{$\begin{array}{c}\text { Crude protein } \\
(\%)\end{array}$} & \multicolumn{2}{|c|}{$\begin{array}{l}\text { Protein yield } \\
(\mathrm{kg} / \mathrm{ha})\end{array}$} \\
\hline & $1^{\text {st }}$ cut & $2^{\text {nd }}$ cut & $1^{\text {st }}$ cut & $2^{\text {nd }}$ cut \\
\hline \multicolumn{5}{|l|}{ Season 2016} \\
\hline \multicolumn{5}{|l|}{ Cutting date (D) } \\
\hline Early & 12.81 & 13.18 & 579.4 & $566.4 \mathrm{a}$ \\
\hline Late & 12.77 & 13.24 & 643.9 & $534.6 \mathrm{~b}$ \\
\hline$F$ test & NS & NS & NS & $*$ \\
\hline \multicolumn{5}{|l|}{ Nitrogen fertilizer levels $(\mathrm{N})$} \\
\hline $35 \mathrm{~kg}$ & $12.26 \mathrm{~b}$ & $12.72 \mathrm{~b}$ & $352.6 \mathrm{c}$ & $490.9 \mathrm{~b}$ \\
\hline $70 \mathrm{~kg}$ & $12.84 \mathrm{a}$ & $13.29 \mathrm{ab}$ & $588.3 \mathrm{~b}$ & $554.4 \mathrm{a}$ \\
\hline $105 \mathrm{~kg}$ & $13.27 \mathrm{a}$ & $13.61 \mathrm{a}$ & $894.0 \mathrm{a}$ & $606.2 \mathrm{a}$ \\
\hline$F$ test & $*$ & $*$ & $* *$ & $*$ \\
\hline Interactions $\mathrm{D} \times \mathrm{N}$ & NS & NS & NS & $*$ \\
\hline \multicolumn{5}{|l|}{ Season 2017} \\
\hline \multicolumn{5}{|l|}{ Cutting date (D) } \\
\hline Early & 11.33 & 12.05 & 400.6 & 377.7 \\
\hline Late & 11.54 & 12.14 & 380.6 & 367.7 \\
\hline$F$ test & NS & NS & NS & NS \\
\hline \multicolumn{5}{|l|}{ Nitrogen fertilizer levels $(\mathrm{N})$} \\
\hline $35 \mathrm{~kg}$ & $10.61 \mathrm{~b}$ & $11.69 \mathrm{~b}$ & $333.3 \mathrm{c}$ & $324.2 \mathrm{~b}$ \\
\hline $70 \mathrm{~kg}$ & $11.56 \mathrm{a}$ & $12.16 \mathrm{ab}$ & $403.8 \mathrm{~b}$ & $398.5 \mathrm{a}$ \\
\hline $105 \mathrm{~kg}$ & $12.13 \mathrm{a}$ & $12.44 \mathrm{a}$ & $434.8 \mathrm{a}$ & $395.5 \mathrm{a}$ \\
\hline$F$ test & $* *$ & * & $* *$ & $*$ \\
\hline Interactions $\mathrm{D} \times \mathrm{N}$ & NS & NS & NS & NS \\
\hline
\end{tabular}

* and $* *$ indicate significance at 0.05 and 0.01 levels, respectively, and NS indicate insignificancy of differences.

4.3.2. Protein Yield ( $\mathrm{kg} / \mathrm{ha})$. Data given in Table 4 disclose that Sudan grass protein yield ( $\mathrm{kg} / \mathrm{ha}$ ) was significantly affected by differences between the early and late cutting date in the first season. Nevertheless, differences reached the nonstatistical level during the second season. Obviously, the early cutting date ( 35 days after the $1^{\text {st }}$ cut) gave significantly a better result than late cutting for this important quality parameter. Achieved protein yield (kg/ha) was higher $(566.4 \mathrm{~kg} / \mathrm{ha})$ at early cutting in the $2^{\text {nd }}$ cut ( 35 days after the $1^{\text {st }}$ cut) compared to that of late cutting at the same $2^{\text {nd }}$ cut 
(42 days after the $1^{\text {st }}$ cut) which gave $534.6 \mathrm{~kg} / \mathrm{ha}$, respectively. Afzal et al. [8] previously confirmed a similar finding that despite delayed cutting might increase the yield, yet the overall quality of Sudan grass may fall. Abo-Zeid et al. [30] and Hassan et al. [36] had reached similar conclusions. While $\mathrm{N}$ levels on the other hand recorded highly significant and significant differences across the two cuts (Table 4). Plainly, increasing the $\mathrm{N}$ fertilizer levels up to the highest level $(105 \mathrm{~kg} \mathrm{~N} / \mathrm{ha} / \mathrm{cut})$ produced significantly the highest protein yield values, but with moreover no differences between 70 and $105 \mathrm{~kg} \mathrm{~N} / \mathrm{ha} /$ cut levels at the $2^{\text {nd }}$ cuts in both seasons. Regarding the interaction effect, the data showed a significant interaction between cutting date and $\mathrm{N}$ fertilizer levels on the protein yield $(\mathrm{kg} / \mathrm{ha})$ of Sudan grass in the $2^{\text {nd }}$ cut of the second season, where the application of the uppermost $\mathrm{N}$ level (105 kg N/ha/cut) under either early or late cutting significantly increased the mean value protein yield $(\mathrm{kg} / \mathrm{ha})$. Otherwise, these results show that increasing the level of $\mathrm{N}$ fertilizer was in favor of increasing the protein yield $(\mathrm{kg} / \mathrm{ha})$ in Sudan grass under the present investigation. Nitrogen fertilization has been suggested to improve not only the yield but also the crude protein content and consequently the protein yield of multicut forage sorghum, of which Sudan grass is an important family member. Iptas and Brohi [37] earlier reported that the CP\% and yield in forage sorghum Sudan grass were not significantly affected by $\mathrm{N}$ levels at the $1^{\text {st }}$ and $3^{\text {rd }}$ cuttings but were significantly affected at the second cutting. Nevertheless, comparable findings on increased crude protein and protein yield with increased $\mathrm{N}$ levels were reported by Anfinrud et al. [23], Moghimi and Emam [25], Naik [35], and Ibrahim et al. [5].

\section{Conclusion}

(1) Delayed cutting of Sudan grass was in favor of obtaining a significantly greater leaf area per plant and heavier dry forage weight (g)/plant. However, the number of shoots per plant seems to decrease with late cutting.

(2) Dry forage yield of Sudan grass increased with delayed cutting, as the highest dry forage yield (ton/ ha) was significantly achieved at the late cutting date compared to early cutting.

(3) The crude protein content and protein yield of Sudan grass increased significantly with increased $\mathrm{N}$ fertilization, while early cutting produced higher protein yield.

(4) Sudan grass proved a high response to nitrogen fertilization as the growth, forage yield, and quality parameters were significantly increased with increased $\mathrm{N}$ fertilizer levels.

Considering the present findings, it is concluded that Sudan grass should be best cut at 56 DAS for the $1^{\text {st }}$ cut and then after 42 and 35 days interval for the $2^{\text {nd }}$ and $3^{\text {rd }}$ cuts, respectively, with application of $105 \mathrm{~kg} \mathrm{~N} / \mathrm{ha} /$ cut as the optimum level for enriched growth, yield, and quality performance under respective agroclimatic conditions.

\section{Data Availability}

The previous studies cited at relevant places within the text are, respectively, documented in references, while any further information on findings of this study is available at any time from the corresponding author upon request.

\section{Conflicts of Interest}

The authors hereby declare that this research was conducted in absence of any commercial and financial relationship that could be constructed as potential conflicts of interest.

\section{References}

[1] S. M. Ismail, F. S. El-Nakhlawy, and J. M. Basahi, "Sudan grass and pearl millets productivity under different irrigation methods with fully irrigation and stresses in arid regions," Grassland Science, vol. 64, no. 1, pp. 29-39, 2018.

[2] FAO, Africa Sustainable Livestock 2050, Country Brief Egypt, Macroeconomic Statistics and Projections: National Accounts, UN Population Fund, UNDP Data, FAOSTAT and OECD. Trade Statistics Elaborated from FAOSTAT, FAO, Rome, Italy, 2017.

[3] M. S. Abd El-Salam, I. M. El-Metwally, H. M. Abd El-Ghany, and M. Hozayn, "Potentiality of using mung bean as a summer legume forage crop under Egyptian condition," Journal of Applied Sciences Research, vol. 9, no. 2, pp. 12381243, 2013.

[4] H. Mahfouz, A. M. M. Ali, E. A. Megawer, and A. S. Mahmoud, "Response of growth parameters, forage quality and yield of dualpurpose sorghum to re-growth and different levels of FYM and N fertilizers in new reclaimed soil," International Journal Current Microbiology and Applied Science, vol. 4, no. 11, pp. 762-782, 2015.

[5] A. M. Ibrahim, E. M. I. Zeidan, H. G. M. Geweifel, I. M. Abd El-Hameed, and S. A. Mahfouz, "Influence of planting density and nitrogen fertilizer levels on fresh forage yield and quality of some forage sorghum genotypes," Zagazig Journal of Agricultural Research, vol. 43, no. 3, pp. 729-743, 2016.

[6] M. A. El-Nahrawy, M. A. El-Geleel, F. Metwalli et al., Country Pasture/Forage Resource Profiles, Egypt, Publishing Policy and Support Branch, Office of Knowledge Exchange, Research and Extension, FAO, Rome, Italy, 2011.

[7] J. Machicek, "Evaluating forage sorghum and pearl millet for forage production and quality in the Texas high plains," M.Sc. thesis, West Texas A \& M University, Canyon, TX, USA, 2018.

[8] M. Afzal, A. Ahmad, and A. H. Ahmad, "Effect of nitrogen on growth and yield of sorghum forage (Sorghum bicolor ( L.) Moench cv.) under three cuttings system," Cercetari Agronomice in Moldova, vol. 45, no. 4, pp. 57-64, 2012.

[9] J. K. Thuranira, A. M. Kibe, J. P. Ouma, and C. K. Kamau, "Effects of cutting time and varieties on fodder grain yields and yield components of sorghum under semi-arid environments of Makueni County in Kenya," International Journal of Sciences: Basic and Applied Research (IJSBAR), vol. 24, no. 5, pp. 309-324, 2015.

[10] I. Atis, O. Konskan, M. Duru, H. Gozubenli, and S. Yilmaz, "Effect of harvesting time on yield, composition and forage quality of some forage sorghum cultivars," International Journal of Agriculture \& Biology, vol. 14, no. 6, pp. 879-886, 2012. 
[11] M. M. Rahman, S. Fukai, and F. P. C. Blamey, "Effects of cutting and sowing date on biomass production and nitrogen content of forage sorghum. school of land and food sciences, the University of Queensland, St Lucia, QLD. 4072, Australia," International Journal of Agriculture and Biology, vol. 14, no. 6, pp. 123-125, 2012.

[12] T. Björkman and J. W. Shail, Cornell Cover Crop Guide for Sudan Grass, Cornell University, New York, NY, USA, 2010.

[13] M. Kaplan, K. Kara, A. Unlukara et al., "Water deficit and nitrogen affects yield and feed value of sorghum Sudangrass silage," Agricultural Water Management, vol. 218, pp. 30-36, 2019.

[14] E. Mansour, A. M. A. Merwad, M. A. T. Yasin, M. I. E. AbdulHamid, E. E. A. El-Sobky, and H. F. Oraby, "Nitrogen use efficiency in spring wheat: genotypic variation and grain yield response under sandy soil conditions," The Journal of Agricultural Science, vol. 155, no. 9, pp. 1407-1423, 2017.

[15] AOAC, Official Methods of Analysis, Association of Official Analytical Chemists, Washington, DC, USA, 13th edition, 1990.

[16] R. G. D. Steel, J. H. Torrie, and D. A. Dicky, Principles and Procedures of Statistics, a Biological Approach, McGraw Hill book Co., New York, NY, USA, 3rd edition, 1997.

[17] D. B. Duncan, "Multiple range and multiple F tests," Biometrics, vol. 11, no. 1, pp. 1-42, 1955.

[18] J. Sowiński and E. Szydełko, "Growth rate and yield of a sorghum-Sudan grass hybrid variety grown on a light and a medium-heavy soil as affected by cutting management and seeding rate," Polish Journal of Agronomy, vol. 4, pp. 23-28, 2011.

[19] E. A. Mahmoud, B. S. H. Ramadan, M. A. Bekheet, and M. A. Gomaa, "Effect of nitrogen fertilization and plant density on productivity and quality of sweet sorghum," American-Eurasian Journal of Agricultural \& Environmental Sciences, vol. 13, no. 5, pp. 654-659, 2013.

[20] I. K. Addai and M. Alimiyawo, "Graphical determination of leaf area index and its relationship with growth and yield parameters of sorghum (Sorghum bicolor L. Moench) as affected by fertilizer application," Journal of Agronomy, vol. 14, no. 4, pp. 272-278, 2015.

[21] M. Mughan, T. Vigot, A. Parrish, G. Bollero, W. Rooney, and D. K. Lee, "Forage and energy sorghum responses to nitrogen fertilization in central and southern Illinois," Agronomy Journal, vol. 104, no. 4, pp. 1032-1104, 2012.

[22] S. O. Yagoub and A. K. Abdelsalam, "Effect of nitrogen and seed rates on growth and yield of forage sorghum (Sorghum bicolor L. Moench cv. Abusabien)," Journal of Science and Technology, vol. 11, no. 2, article 123136, 2010.

[23] R. Anfinrud, L. Cihacek, B. L. Johnson, Y. Ji, and M. T. Berti, "Sorghum and kenaf biomass yield and quality response to nitrogen fertilization in the Northern Great Plains of the USA," Industrial Crops and Products, vol. 50, pp. 159-165, 2013.

[24] S. S. Nirmal, A. V. Solanke, D. D. Dudhade et al., "Response of forage sorghum (Sorghum bicolor (L.) Moench) cultivars to nitrogen levels," International Journal of Science, Environment and Technology, vol. 5, no. 4, pp. 2605-2609, 2016.

[25] N. Moghimi and Y. Emam, "Growth and yield responses of two forage sorghum cultivars to different nitrogen fertilizer rates," Iran Agricultural Research, vol. 34, no. 1, pp. 39-45, 2015.

[26] M. El Zubair, B. Fadlalla, A. H. M. Hussien, and M. Abdelkreim, "Effect of different nitrogen fertilization levels on yield of maize
(Zea mays L.) as winter forage," International Journal of Scientific \& Technology Research, vol. 4, no. 10, pp. 197-201, 2015.

[27] K. S. Somashekar, B. G. Shekara, K. N. Kalyanamurthy, and H. S. Lohithaswa, "Growth, yield and economics of multi-cut fodder sorghum (Sorghum sudanense L.) as influenced by different seed rates and nitrogen levels," Forage Research, vol. 40, no. 4, pp. 247-250, 2015.

[28] R. D. Ramamohan, "Response of multicut fodder sorghum (Sorghum bicolor (L.) Moench) to nitrogen and zinc," M.Sc. thesis, Acharya N. G. Ranga Agricultural University, Bapatla, India, 2010.

[29] M. H. Shahrajabian and A. Soleyman, "Responses of physiological indices of forage sorghum under different plant populations in various nitrogen fertilizer treatments," International Journal of Plant \& Soil Science, vol. 15, no. 2, pp. 1-8, 2017.

[30] S. T. Abo-Zeid, A. L. Abd El-Latif, and S. El Shafey, "Effect of sources and rates of nitrogen fertilizers on forage yield and nitrate accumulation for Sudan grass," Egyptian Journal of Soil Science, vol. 57, no. 1, pp. 23-30, 2017.

[31] B. J. Karthikeyan, C. Babu, and J. J. Amalraj, "Nutritive value and fodder potential of different Sorghum (Sorghum bicolor $\mathrm{L}$. Moench) cultivars," International Journal of Current Microbiology and Applied Sciences, vol. 6, no. 8, pp. 898-911, 2017.

[32] K. McCuistion, Nutritional Guide to Feeding Sorghum, Texas A \& M University-Kingsville, Kingsville, TX, USA, 2016.

[33] L. K. Midha, A. Satyawanand, and U. N. Joshi, "Response of forage sweet sorghum genotypes under different nitrogen levels," Forage Research, vol. 40, no. 2, pp. 116-118, 2014.

[34] E. G. El Shafey, "Nitrogen accumulation in some forage crops," M.Sc. thesis, Agricultural Sciences, Faculty of Agriculture, Cairo University, Giza, Egypt, 2015.

[35] G. Naik, "Effect of different fertility levels on growth and fodder yield of sweet sorghum," M.Sc. thesis, Department of Agronomy College of Agriculture, Jawaharlal Nehru Krishi Vishwa Vidyalaya, Jabalpur, India, 2016.

[36] M. U. Hassan, M. U. Chattha, M. B. Chattha, A. Mahmood, and S. T. Sahi, "Impact of harvesting times on chemical composition and methane productivity of sorghum (Sorghum bicolor Moench L.)," Applied Ecology and Environmental Research, vol. 16, no. 3, pp. 2267-2276, 2018.

[37] S. Iptas and A. R. Brohi, "Effect of nitrogen rate and stubble height on dry matter yield, crude protein content and crude protein yield of a sorghum-Sudangrass hybrid [Sorghum bicolor (L.) Moench $\times$ Sorghum sudanense (piper) Stapf.] in the three-cutting system," Journal of Agronomy and Crop Science, vol. 189, no. 4, pp. 227-232, 2003. 


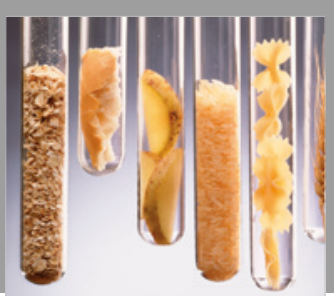

International Journal of Food Science

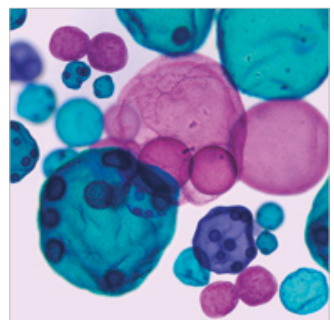

International Journal of Microbiology
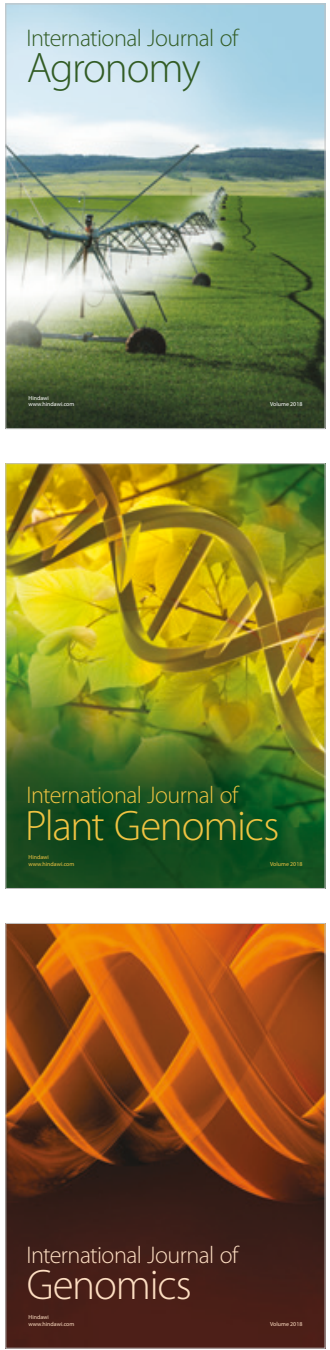

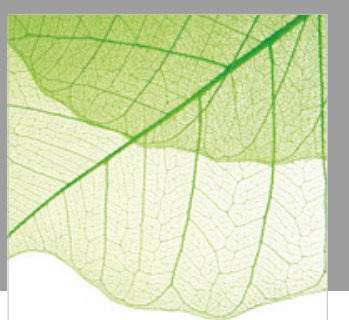

Journal of Botany
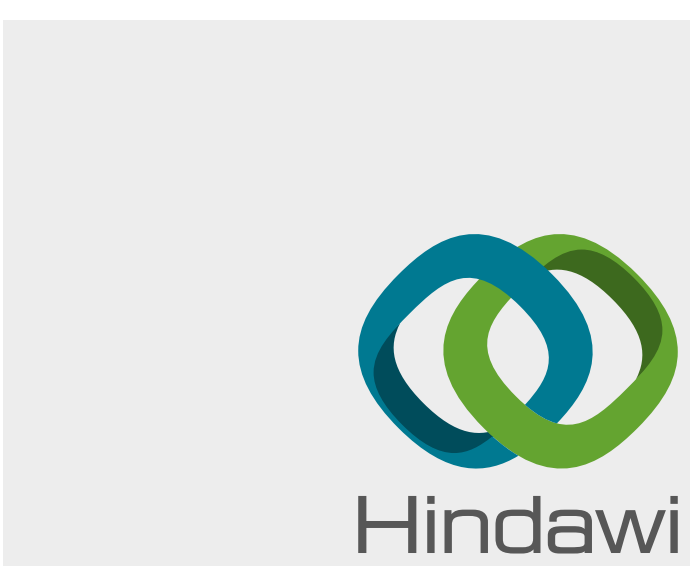

Submit your manuscripts at

www.hindawi.com
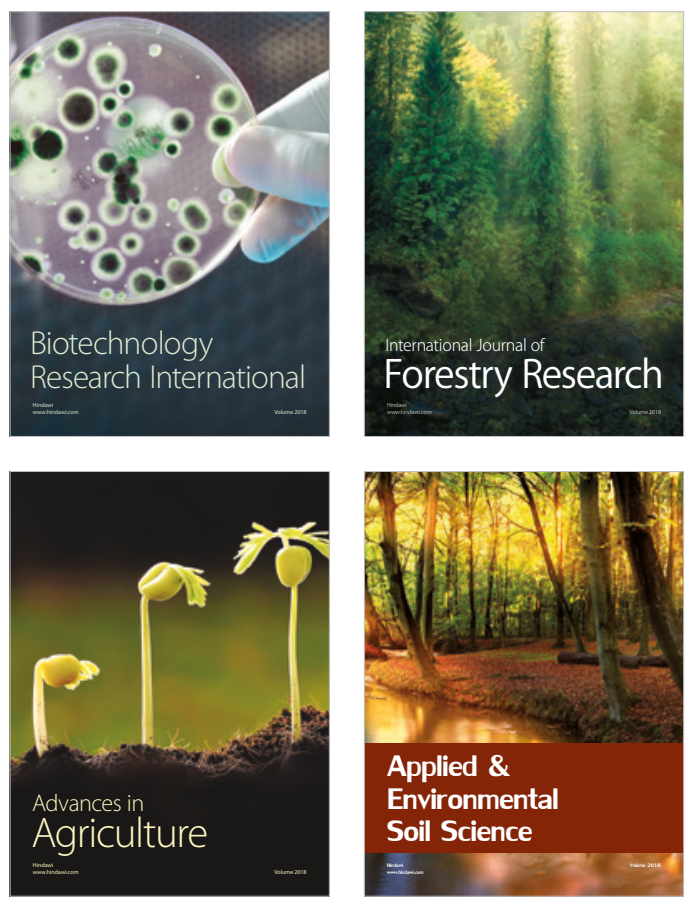

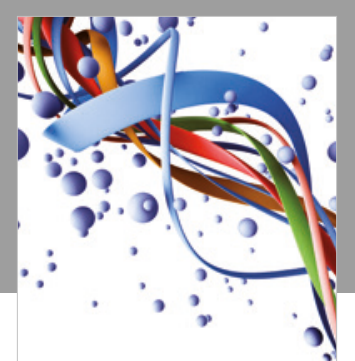

Scientifica

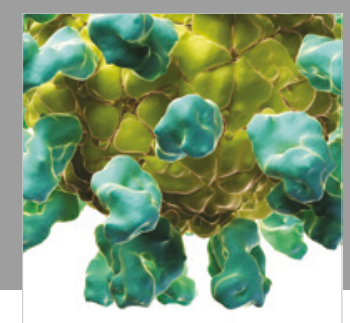

Veterinary Medicine International

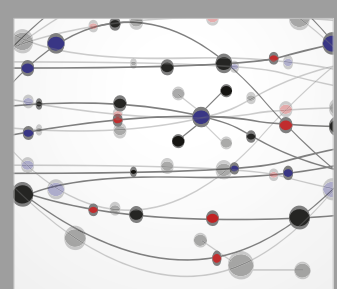

The Scientific World Journal
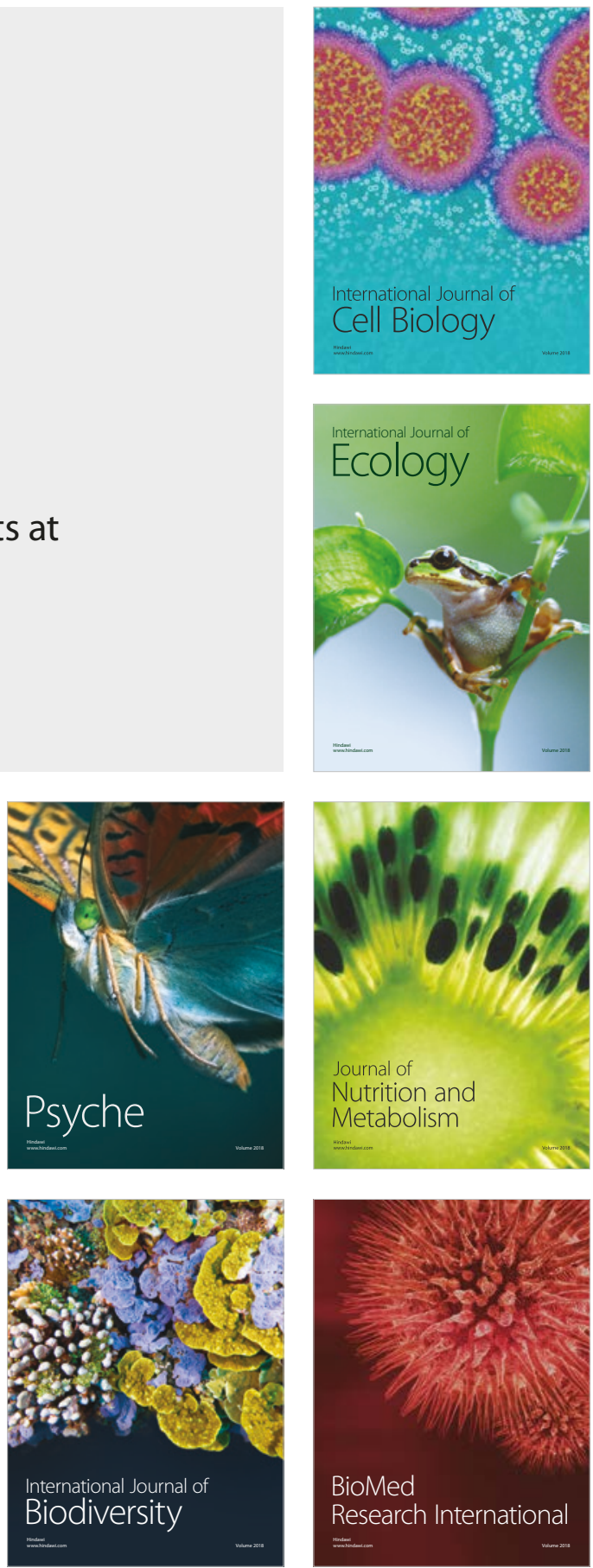